\title{
INTELLECTUAL AND PSYCHIC UNDERDEVELOPMENT OF CHILDREN IN ORPHANAGES AND FAMILY SUPPORT SERVICE AS POSSIBLE SOLUTIONS TO DECLARED ISSUES \\ Akhmetov R.R. (Russian Federation) Email: Akhmetov332@scientifictext.ru
}

\author{
Akhmetov Radmir Rustemovich - Student, \\ PETROLEUM ENGINEERIND DEPARTMENT, \\ SAINT PETERSBURG MINING UNIVERSITY, \\ SAINT PETERSBURG
}

\begin{abstract}
: in this paper was said that emotional, social and sensory deprivation results in such psychic deviations as aggression, self-torture, rocking, hand-flapping and many others. Deficiency of attention, cognitive work, action scheduling and abstract thinking leads to the fact that after 3 years of studying in Russia only 59\% of children continue education and $30 \%$ of kids were accused in stealing. Afterwards this paper looks at possible solutions to declared issues. As 94\% of children's living in institutions parents is alive and family support service costs 9 times lower than institutional placement. The evidence of remedy's benefit is provided by fact that Romania started a huge program of enhancing family support services $n$ early 1990s. In 1994, there were 200,000 children living in institutions, and more entering every day. Now, there are less than 10,000.

Keywords: orphanages, psychic underdevelopment, intellectual underdevelopment, family support services, cognitive work.

\section{ИНТЕЛЛЕКТУАЛЬНОЕ И ПСИХОЛОГИЧЕСКОЕ ОТСТАВАНИЕ В РАЗВИТИИ ДЕТЕЙ В ДЕТСКИХ ДОМАХ И ПОДДЕРЖКА СЕМЬИ КАК ГЛАВНОЕ РЕШЕНИЕ ПРОБЛЕМЫ ОТСТАВАНИЯ Ахметов Р.P. (Российская Федерация)}

\author{
Ахметов Радмир Рустемович - студент, \\ кафедра транспорта и хранения нефти и газа, \\ Санкт-Петербургский горный университет, г. Санкт-Петербург
}

\begin{abstract}
Аннотация: в статье говорится, что эмочиональная, сочиальная и чувственная депривации становятся причиной таких девиаџий, как агрессия, самоистязание, качание и многих других. Недостаток внимания, когнитивной работы, расписания и абстрактного мышления приводит к тому, что после 3 лет обучения в школе в России только 59\% детей продолжают обучение, а 30\% обвиняются в воровстве. У 94\% детей в детских домах есть живые родители и служба поддержки семьи стоит в 9 раз меньше, чем содержание ребенка в детском доме. Доказательством полезности данной меры также служст тот факт, что в Румынии в начале 1990 годов начали развитие большой программы поддержки семьи. В 1994 году в Румынии в детских домах было 200000 детей, а сейчас менее 10000.
\end{abstract}

Ключевые слова: детский дом, отставание в развитии интеллекта, отставание в развитии психики, поддержка семьи, когнитивная работа.

According to distinguished figure in psychology, Leon Yarrou, there are 3 reasons of psychic underdevelopment: emotional, social, sensory deprivations.

The emotional deprivation is about the lack of love and reciprocal feelings. Indeed the peculiarity of family education is its affective tone, which is based on deep loyalties. Therefore all psychologist acknowledge the great impact of such emotions on children' psychic. We are proceeding to social deprivation. In fact kids who grow up in families learn not only how to talk and eat but also how to think, feel and empathize. Thus they naturally join in life with its rules and factors. Kids in orphanage do not have this opportunity. As well as they have no chance to communicate with loved ones to develop crucial social skills. Finally, we are coming to sensory deprivation. It is well known that children in mentioned establishments have strict regime. In addition their impressions are so monotonous, that as a matter of fact, their life is close to a life of a prisoner and sometimes even worse. You can imagine how harmful is this lifestyle to kids psychic [1, 2]. Generalizing all stated reasons we can call all of them the absence of upbringing. These factors lead to severe underdevelopment of kids psychic (Figure 1). 


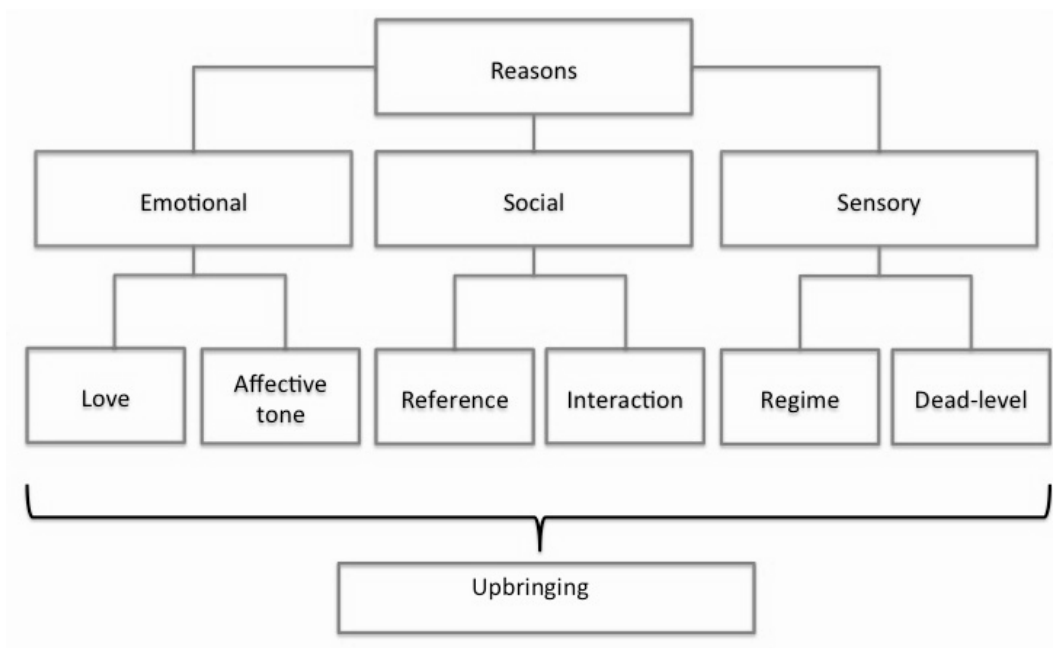

Fig. 1. Scheme of psychic underdevelopment reasons

Over the years, many people and news reports have blamed the personnel in the institutions for the harm caused to children, but often, one member of staff is caring for 20, and even 30 children. Hence they have no option but to implement a regimented program. That is why in a room of 30 newborns, not one of them cries. You can see that some of the children are distressed, but the only noise is a low, continuous moan.

The newly admitted babies cry for the first few hours, but their demands are not met, and so eventually they learn not to bother. Within a few days, they are listless, lethargic, and staring into space like all the others.

Lack of stimulation often leads to self-stimulating behaviors like hand-flapping, rocking back and forth, or aggression, and in some institutions, psychiatric drugs are used to control the behavior of these children, whilst in others, children are tied up to prevent them from harming themselves or others. These children are quickly labeled as having disabilities and transferred to another institution for children with disabilities. Most of these children will never leave the institution again. For those without disabilities, at age three, they're transferred to orphanage $[5,6]$.

In that institution their psychic becomes even worse and most of kids become too self-absorbed and partly because of that their self-esteem is often not adequate. Some kids become too active or in contrast listless and nonchalant. An international study found that legally free children experience less positive emotions than their peers who are raised in families. Kids also show lack of empathy which often results in severity. The older children bully the little ones. They learn to survive. They learn to defend themselves, or they go under.

The communication between these kids and adults also have some peculiarities. The fact is that children commence considering adults as useful tools for their purposes. In addition they try to draw too much attention. Also the relationship have dramatic character which means that if you come to an orphanage, it is more likely that these children will hug and kiss you than talk.

In addition to problems with psychic, kids in these establishments have an intellectual underdevelopment. It is important to mention that experiments prove that this occurs due to their living conditions and sometimes unqualified teachers and definitely not because of heredity factor. So this leads to the serious decrease of attention, scheduling, cognition and abstract thinking. A great illustration of this is that kids find difficult to answer some simple questions like what do you like? Or How do you feel about this?

We can also mention the disruptive behavior. For instance, it was found that around $30 \%$ of residential school students regularly steal some articles or money. All these factors lead to a shocking data. $41 \%$ of residential school students in Russia are transferred to special school [3, 4, 10] (Figure 2). 


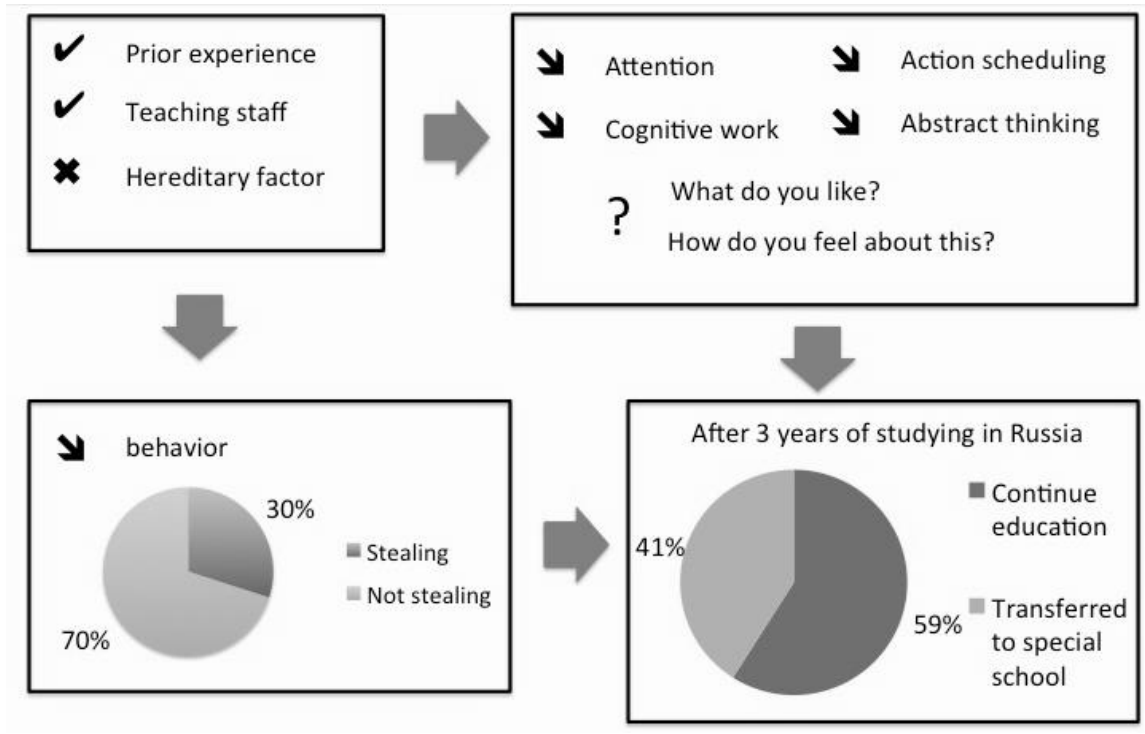

Fig. 2. Scheme of intellect underdevelopment.

According to most eminent sociologists, psychologies and psychiatrists there are 3 basic ways of tackling stated problem. We can upsurge the ammount of custodies, reform the institutional structure or enhance family support service.

It can be started with family support service. Firstly, let us name the reasons why children are taken in orphanages, inphant orphanages or residential schools. In can be shocking but $68 \%$ are in istitutions due to deprivation of parental rights, 8 , because single parents rejected them, $7 \%$ because of relinquishment of parental rights, the parents of $4 \%$ children in institutions are in prison, $7 \%$ parents are incapable and only $6 \%$ of legally free children are orphans. So as a matter of fact $94 \%$ of this kids parents are alive of which $87 \%$ are capable to raise them and only $7 \%$ do not have ability to foster their children (Figures 3,4$)[8,11]$.

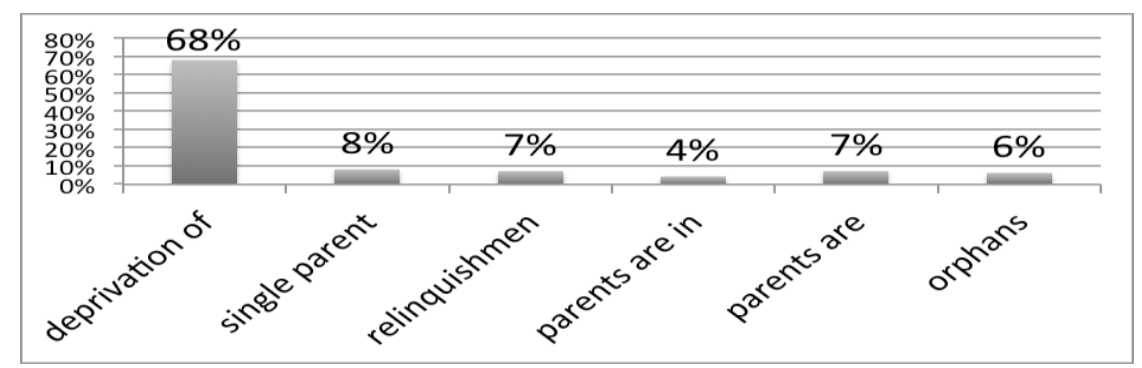

Fig. 3. Reasons why children are in orphanage

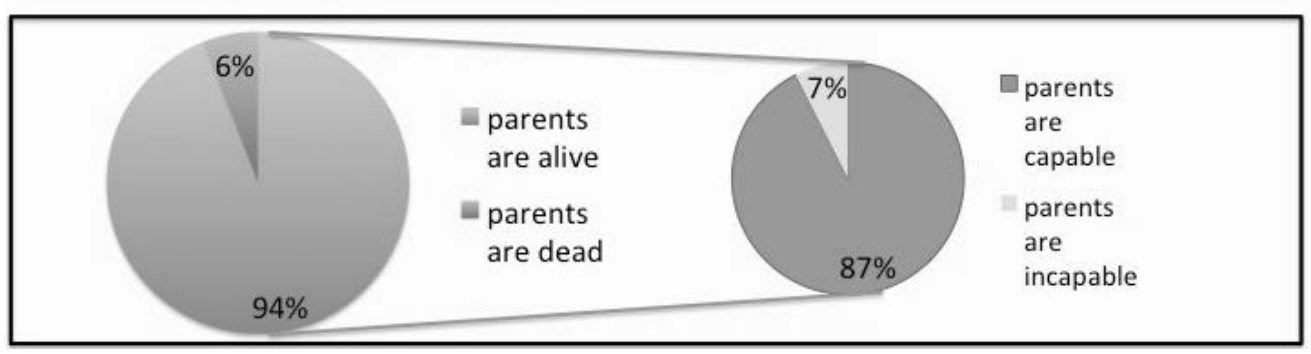

Fig. 4. Reasons why parents leave their children

Romania started a huge program of enhancing family support services n 1990s. Now family support services are provided across the country. Nearly 20 years ago, there were 200,000 children living in institutions, and more entering every day. Now, there are less than 10,000. In addition, one study suggests that a family support service costs 10 percent of an institutional placement [7, 10]. That's why The European Commission and other major donors are finding ways to divert money from institutions towards family support.

It must be added that sometimes parents send their children to institution not because they are cruel but because they think that they have no choice. For instance, imagine mother who only had enough money to feed her baby, and so had to send her older son to the institution or the young couple who have just found out that their firstborn child has a disability are told by the doctors, "Forget her, leave her in the institution, go home and make a healthy one." 
Family support service can give them that option (Figures 5, 6).

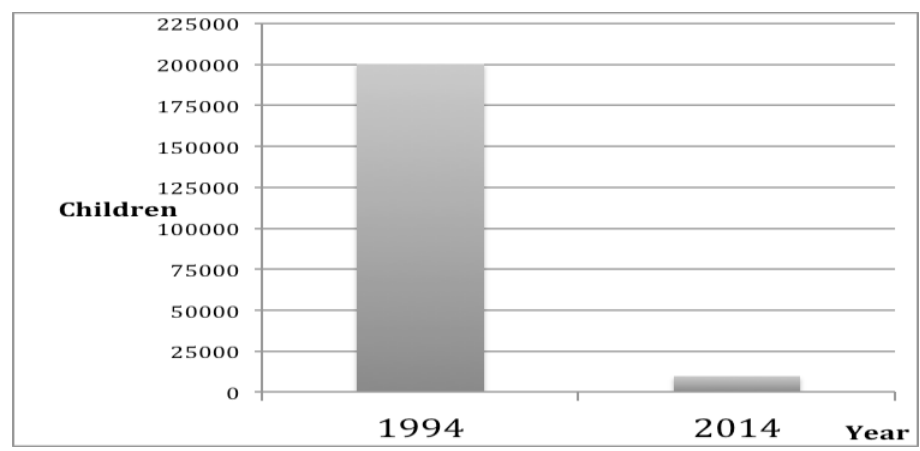

Fig. 5. Children living in institutions in Romania

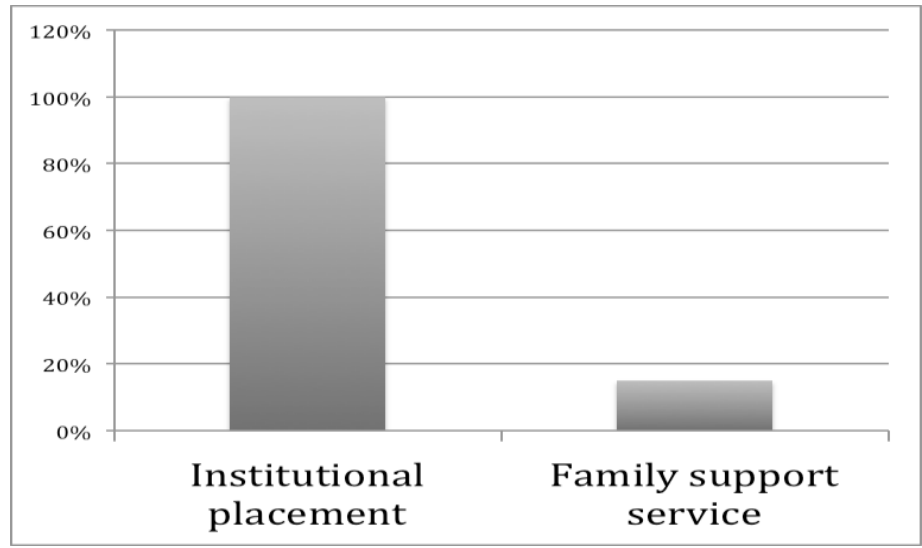

Fig. 6. Cost of measures

\section{References / Сиисок литературы}

1. Bykov A.V., Shulga T.I., Oliferenk, L. Ya. Socio-psychological assistance to disadvantaged children. / A.V. Bykov, T. Shulga, L.Y. Oliferenko. Moscow: URAO, 2003.

2. Peskova M.E. Features of the formation of life experience in pupils of orphanages. / M.E. Peskova // Defectology. № 5, 2007. Pp. 75-83.

3. Dubrovina I.V. Workbook of the school psychologist. Moscow: Enlightenment, 1991. P. 303.

4. Dubrovina I.V. Psychological development of pupils of orphanages. M., 1990.

5. Open data of the Ministry of Education and Science of the Russian Federation. Department of State Policy for the Protection of Children's Rights.

6. Shapar V.B. The newest psychological dictionary. Under the general ed. Shapar V.B. 3. Rostov, 2007. P 806.

7. Shipitsyn L..M .Psychology of orphans; Publishing house of St. Petersburg. University, 2005. 628 p.

8. Elkonin D.B. Children's psychology: Textbook. Moscow: Publishing Center "Academy", 2004. 384 p.

9. Federal Service of State Statistics of Russia.

10. Statistical collection "Children in Russia", 2009. M: Rosstat.

11. Parishioners A.M. Psychology of orphanhood. (Text). 3. St. Petersburg, 2007. 416 p. 